\title{
Si-TCP Synthesized from "Mg-free" Reagents Employed as Calcium Phosphate Cement
}

\author{
Mariana Motisuke ${ }^{\mathrm{a}, \mathrm{b} *}$, Raul García Carrodeguas ${ }^{\mathrm{c}}$, Cecília Amélia de Carvalho Zavaglia ${ }^{\mathrm{b}, \mathrm{d}}$ \\ anstituto de Ciência e Tecnologia, Universidade Federal de São Paulo - UNIFESP, \\ São José dos Campos, Brasil \\ ' INCT-Biofabris, Campinas, Brasil \\ ${ }^{\mathrm{I}}$ ICV - CSIC, Madrid, España \\ ${ }^{\mathrm{d}}$ Labiomec, Faculdade de Engenharia Mecânica, Universidade Estadual de Campinas - UNICAMP, \\ Campinas, Brasil
}

Received: February 23, 2012; Revised: April 17, 2012

\begin{abstract}
The influence of silicon doping on calcium phosphate cement were explored in this work. $\alpha$-TCP and $\mathrm{Si}-\alpha$-TCP were prepared by solid state reaction employing "Mg-free" $\mathrm{CaHPO}_{4}$, $\mathrm{CaCO}_{3}$ and $\mathrm{CaSiO}_{3}$ as precursors. It was possible to obtain TCP powders with low contents of $\beta$ phase as contaminant. Cement liquid phase was an aqueous solution containing 2.5 wt. (\%) of $\mathrm{Na}_{2} \mathrm{HPO}_{4}$ and $1.5 \mathrm{wt}$. (\%) of citric acid. The liquid-to-powder ratio was $0.6 \mathrm{~mL} \cdot \mathrm{g}^{-1}$. Chemical, physical and mechanical properties of the cement samples were determined by means of XRD, FTIR, XRF, compressive strength and SEM. The calcium phosphate cements obtained achieved satisfactory properties; however, $\mathrm{Si}-\alpha-\mathrm{TCP}$ presented a decrease on the rate of setting reaction.
\end{abstract}

Keywords: calcium phosphate cements, Si-doped calcium phosphates, bioceramics

\section{Introduction}

The need for new biomaterials which could improve life quality of people who suffer from oldness diseases or who have any bone tissue injury due to accidents and diseases like obesity and cancer are resulting in a growing number of researches. In this context, the development of new orthopedics biomaterials based on calcium phosphate compounds is relevant once they present excellent bioactivity and biocompatibility due to its chemical composition similar to the mineral part of bone and teeth ${ }^{1-3}$.

Silicon substitution into some phosphorous sites of calcium phosphate bioceramics is a promising approach to develop new biomaterials for orthopedics applications due to the increased bioactivity and cell differentiation on the material's surface which could be promoted by the presence of this element ${ }^{4-11}$. Therefore, silicon doped $\alpha$-tricalcium phosphate (Si- $\alpha$-TCP), is attracting the attention of researchers since its employment as bone cement could be of great interest. Nevertheless, it is still not well stabilished if the enhanced biological properties of the silicon doped calcium phosphates compounds is due to the presence of silicon itself or it is because of its influence on the chemical properties of the material ${ }^{12-14}$.

Moreover, silicon is known to stabilize the $\alpha$-tricalcium phosphate, $\alpha$-TCP, structure and to promote its formation at lower temperature ${ }^{15,5,16,17}$ leading to a cost reduction of its processing. It is well known that the synthesis of a pure $\alpha$-TCP is not an easy task since all process conditions can change its final properties, or even inhibit its formation. The most limiting factor is the quality of the starting reagents which may preclude the formation of $\alpha-\mathrm{TCP}$ at temperatures

*e-mail: motisuke@unifesp.br as high as $1600{ }^{\circ} \mathrm{C}^{10,13}$. Therefore, the reproducibility of $\alpha$-TCP synthesis becomes very difficult and, in some cases, impossible. In a previous work, our group has developed simple synthetic methods to synthesize high purity reagents to eliminate the most important impurity: magnesium, which is an established stabilizer element of $\beta$-tricalcium phosphate, $\beta$-TCP ${ }^{16}$. It has been discovered that the standardization of the reagents properties guaranteed the reproducibility of $\alpha$-TCP manufacturing process and the formation of a high purity $\alpha$-TCP and $\mathrm{Si}-\alpha-\mathrm{TCP}$. Thus, the major objective of this study is to investigate the influence of $\mathrm{Si}$ on the chemical, physical and mechanical properties of the calcium phosphate cement.

\section{Material and Methods}

\subsection{TCP precursors and TCP powders synthesis}

"Mg-free" $\mathrm{CaHPO}_{4}$ and $\mathrm{CaCO}_{3}$ were synthesized by aqueous solution precipitation in the presence of ethylenediamine tetraacetic acid (EDTA). $\mathrm{CaSiO}_{3}$ were synthesized by solid state reaction of "Mg-free" $\mathrm{CaCO}_{3}$ and electronic grade $\mathrm{SiO}_{2}$, which was kindly provided by the Photonic Materials Laboratory-UNICAMP, Brazil ${ }^{16}$.

Afterwards, two tricalcium phosphate powders, $\alpha$-TCP and $\mathrm{Si}-\alpha-\mathrm{TCP}$, were synthesized by solid state reaction. The syntheses parameters are displayed in Table 1. For $\alpha$-TCP, a stoichiometric mixture of $\mathrm{CaCO}_{3}(<0.02$ wt. (\%) of $\mathrm{Mg})$ and $\mathrm{CaHPO}_{4}(<0.0001$ wt. $(\%)$ of $\mathrm{Mg})$ was fired at $1300{ }^{\circ} \mathrm{C}$. Meanwhile, Si- $\alpha$-TCP was obtained by adding 2 wt. (\%) of $\mathrm{CaSiO}_{3}(<0.0001$ wt. $(\%)$ of $\mathrm{Mg})$ to the mixture of $\mathrm{CaHPO}_{4}$ and $\mathrm{CaCO}_{3}$. The firing temperature was $1250{ }^{\circ} \mathrm{C}$. For both 
materials heating rate was $10{ }^{\circ} \mathrm{C} / \mathrm{min}$ and after the dwelling time (6 hours) the samples were let to cool inside the furnace without quenching. Finally, the powders were ball milled for 48 hours.

\subsection{Calcium phosphate cements}

Cement samples were prepared using an aqueous solution containing 2.5 wt. (\%) of $\mathrm{Na}_{2} \mathrm{HPO}_{4}$ and $1.5 \mathrm{wt}$. (\%) of $\mathrm{C}_{6} \mathrm{H}_{8} \mathrm{O}_{7}$ (citric acid) with a liquid-to-powder ratio equal to $0.60 \mathrm{~mL} \cdot \mathrm{g}^{-1}$. After molding in Teflon molds $(6 \times 12 \mathrm{~mm})$ samples were left in a $100 \%$ relative moisture environment for 24 hours. Then, cement cylinders were polished, demolded and immersed in simulated body fluid (SBF) for 24 and 168 hours at $37{ }^{\circ} \mathrm{C}$. After each immersion period, samples were gently rinsed with distillated water, immersed in acetone to stop the setting reaction and dried at $100{ }^{\circ} \mathrm{C}$ for 6 hours.

\subsection{Characterizations}

TCP powders and cement samples crystalline phase analyses were carried out by means of qualitative $X$ ray diffraction (Rigaku DMAX 2200, 20-40 $(2 \theta), 0.01^{\circ}(2 \theta) / \mathrm{s}$, $40 \mathrm{~mA}$ and $20 \mathrm{kV}$ ). JCPDS files used for phase identification were 09-0348 for $\alpha$-TCP, 09-0169 for $\beta$-TCP and 46-0905 for calcium deficient hydroxyapatite, CDHA. Moreover, a quantitative XRD analysis was performed to quantify $\beta$-TCP on the TCP powders. It was employed the internal pattern method in which a diffraction line from the phase being quantified is compared with a diffraction line from a standard mixed with

Table 1. TCP powders synthesis parameters.

\begin{tabular}{cccccc}
\hline Sample & $\begin{array}{c}\mathrm{CaSiO}_{3} \\
(\text { wt. }(\%))\end{array}$ & $\begin{array}{c}\mathrm{Mg} \\
\text { (wt. }(\%))\end{array}$ & $\begin{array}{c}\text { T } \\
\left({ }^{\circ} \mathbf{C}\right)\end{array}$ & $\begin{array}{c}\text { Heating rate } \\
\left({ }^{\circ} \mathbf{C} / \mathbf{m i n}\right)\end{array}$ & $\begin{array}{c}\text { Dwell time } \\
(\text { hours })\end{array}$ \\
\hline$\alpha-\mathrm{TCP}$ & 0 & 0.0059 & 1300 & & \\
$\mathrm{Si}-\mathrm{TCP}$ & 2 & 0.0058 & 1250 & 10 & 6 \\
\hline
\end{tabular}

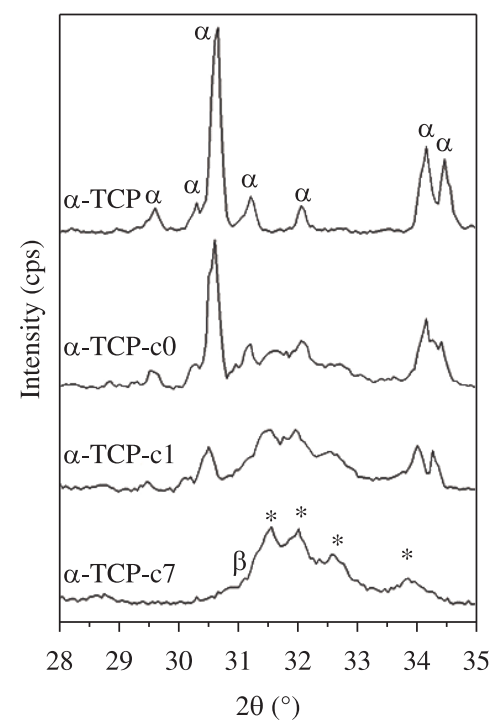

the sample in known proportions ${ }^{18}$. The standard employed was $\mathrm{Al}_{2} \mathrm{O}_{3}$ and $\beta$-TCP diffraction line used was (2 14 ).

Chemical composition of the samples were evaluated by means of fourier transformed infrared spectroscopy. Samples were diluted in $\mathrm{KBr}$ and analyzed in a Perkin Elmer 1600 FT-IR spectrometer with a scanning range from 450 to $4000 \mathrm{~cm}^{-1}$ and resolution of $2 \mathrm{~cm}^{-1}$.

Powders stoichiometry was determined by quantitative X-ray fluorescence (MagiX Super Q Version 3.0 X-ray fluorescence spectrometer, Philips, The Netherlands). Samples were weighed at $0.3000 \mathrm{~g}$, mixed with $5.5 \mathrm{~g}$ of spectral grade $\mathrm{Li}_{2} \mathrm{~B}_{4} \mathrm{O}_{7}$ and melted in a $\mathrm{Pt} / \mathrm{Au}$ crucible and formed into disks in a special controlled furnace Perl'X3 (Philips, The Netherlands). Calibration curves were prepared using certified composition standards of natural and synthetic calcium phosphates and calcium silicates. Finally, BET specific surface area and particle size distribution were determined using a Micromeritics ASAP 2010 and a Malvern Mastersizer S, respectively.

Cement setting times were determined using the ASTM-C266-04 standard ${ }^{19}$. Cement samples compressive strength after each time of setting were determined using a MTS, Test Star II with a $10 \mathrm{kN}$ cell attached and a compression velocity of $1 \mathrm{~mm} / \mathrm{min}$. The fracture surface was gold coated (BAL-TEC, SCD 050) and its morphology was analyzed on a scanning electron microscope (JEOL, JXA-840A).

\section{Results}

For both samples it was possible to obtain TCP powders in its $\alpha$-TCP form as can be observed on XRD diffractograms of Figure 1 . The contents of $\beta$-TCP were very low: 8 and 4 wt. (\%) for $\alpha$-TCP and Si- $\alpha$-TCP, respectively. Powders stoichiometry is displayed on Table 2, $\mathrm{Ca} / \mathrm{P}$ and $\mathrm{Ca} / \mathrm{P}+\mathrm{Si}$ ratios were 1.50 and 1.46 , respectively.

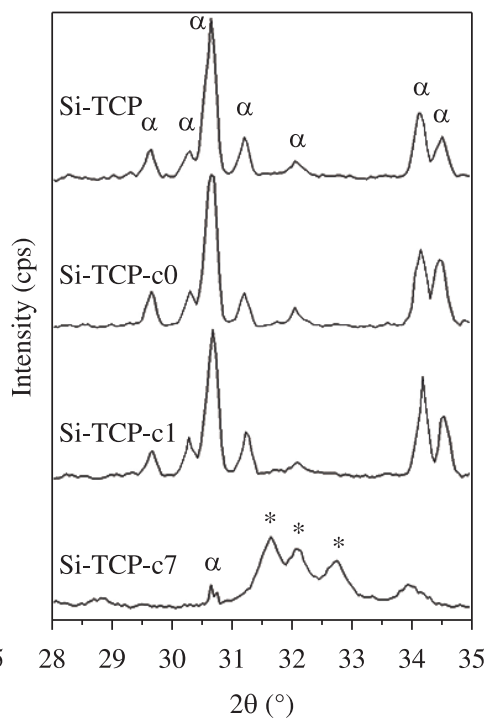

Figure 1. XRD patterns of powders and cement samples. Cement samples: after 24 hours at $100 \%$ of relative moisture $(\alpha-$ TCP-c0 and $\mathrm{Si}$-TCP-c0), 1 day in Ringer ( $\alpha$-TCP-c1 and Si-TCP-c1) and 7 days in Ringer $(\alpha-$ TCP-c7 and Si-TCP-c7). $\beta$-TCP weight content are 4 wt. (\%) for Si-TCP and 8 wt. (\%) for $\alpha$-TCP. Legend: $\alpha=\alpha$-TCP and $\beta=\beta$-TCP and $*=$ apatite. 
Table 2. BET specific surface area, $\mathrm{Ca} / \mathrm{P}$ or $\mathrm{Ca} /(\mathrm{P}+\mathrm{Si})$ ratios and particle size distribution.

\begin{tabular}{cccrc}
\hline Sample & BET $\left(\mathbf{m}^{2} \cdot \mathbf{g}^{-1}\right)$ & $\mathbf{C a} / \mathbf{P}$ or $\mathbf{C a} /(\mathbf{P}+\mathbf{S i})$ & \multicolumn{1}{c}{$\mathbf{d}_{\text {Mean }}(\boldsymbol{\mu m})$} & $\mathbf{1 0 \%}<\mathbf{d}<\mathbf{9 0 \%}(\boldsymbol{\mu m})$ \\
\hline$\alpha$-TCP & $0.8030 \pm 0.0125$ & 1.50 & $9.61 \pm 0.14$ & $1.08 \pm 0.02-20.42 \pm 0.29$ \\
Si-TCP & $0.6930 \pm 0.0033$ & 1.46 & $10.68 \pm 0.08$ & $1.51 \pm 0.01-20.33 \pm 0.18$ \\
\hline
\end{tabular}

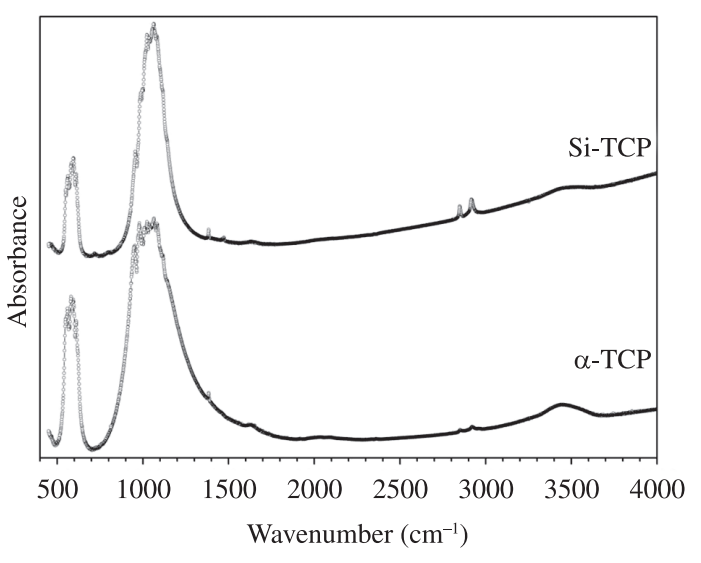

Figure 2. FTIR spectrum of TCP powders.

The effectiveness of the solid state reaction employed was also elucidated by FTIR analysis since the absorption bands present on both spectrums (Figure 2) are characteristic of $\alpha$-TCP as displayed on Table $3^{20}$.

Moreover, both TCP powders have very similar BET specific surface area $(0.8030 \pm 0.0125$ and $0.6930 \pm 0.0033 \mathrm{~m}^{2} / \mathrm{g}$ for $\alpha-\mathrm{TCP}$ and for $\mathrm{Si}-\mathrm{TCP}$, respectively) and particle size distribution after 48 hours of ball milling. The mean particle diameter was $9.61 \pm 0.14 \mu \mathrm{m}$ for $\alpha$-TCP and $10.68 \pm 0.08 \mu \mathrm{m}$ for Si-TCP. This results are resumed on Table 2 .

Cement setting times are displayed on Table 4. For both cements the values obtained using the Gilmore Needles ${ }^{19}$ were higher when compared to the values reported on the literature $^{20,21}$. Initial setting time was 15 minutes for $\alpha$-TCP and 30 minutes for Si- $\alpha$-TCP. Moreover, final setting time was 43 minutes for $\alpha$-TCP and 120 minutes for Si- $\alpha$-TCP.

As can be observed on XRD patterns of Figure $1 \alpha-$ TCP and $\mathrm{Si}-\alpha-\mathrm{TCP}$ setting reaction occurs by the dissolution of TCP phase and the precipitation of apatite crystals once these are the only crystalline phases observed during the role process. Indeed, as displayed on the FTIR spectrums of Figure 3 the apatite phase formed are calcium deficient hydroxyapatite $\left(\mathrm{CDHA}, \mathrm{Ca}_{9}\left(\mathrm{HPO}_{4}\right)\left(\mathrm{PO}_{4}\right)_{5} \mathrm{OH}\right)$ since their characteristics absorption bands (Table 5) are present in both spectrums. Moreover, it is possible to verify that both cements lead to an apatite phase which is also carbonated due to the $\mathrm{CO}_{3}{ }^{2-}$ characteristics bands at 850 to 900 and at 1350 to $1600 \mathrm{~cm}^{-1}$ (highlighted with a “*” on Figure 3).

Cement's mechanical strength evolution with time of SBF immersion can be observed on Figure 4. It is verified that $\mathrm{Si}-\alpha$-TCP resulted on lower values of compressive strength after 7 days of immersion. Moreover, during the first day of immersion, Si- $\alpha$-TCP did not achieve any mechanical resistance while $\alpha$-TCP achieved values around $5 \mathrm{MPa}$.
Table 3. FTIR absorption bands of $\alpha-\mathrm{TCP}^{20}$.

\begin{tabular}{ccc}
\hline Absorption & Bond & Wavenumber $\left[\mathbf{c m}^{-\mathbf{1}}\right]$ \\
\hline$v_{1}$ & $\mathrm{P}-\mathrm{O}$ & 963 \\
$v_{2}$ & $\mathrm{OPO}$ & 462 \\
& & 1120 \\
& & 1100 \\
$v_{3}$ & $\mathrm{P}-\mathrm{O}$ & 1084 \\
& & 1025 \\
& & 990 \\
& & 597 \\
& & 583 \\
$v_{4}$ & OPO & 572 \\
& & 559 \\
\hline
\end{tabular}

Table 4. Setting times of cement samples. $T_{i}=$ initial setting time and $\mathrm{T}_{\mathrm{f}}=$ final setting time .

\begin{tabular}{ccc}
\hline Sample & $\mathbf{T}_{\mathbf{i}}[\mathbf{m i n}]$ & $\mathbf{T}_{\mathbf{f}}[\mathbf{m i n}]$ \\
\hline Si-TCP & 30 & 120 \\
$\alpha-\mathrm{TCP}$ & 15 & 43 \\
\hline
\end{tabular}

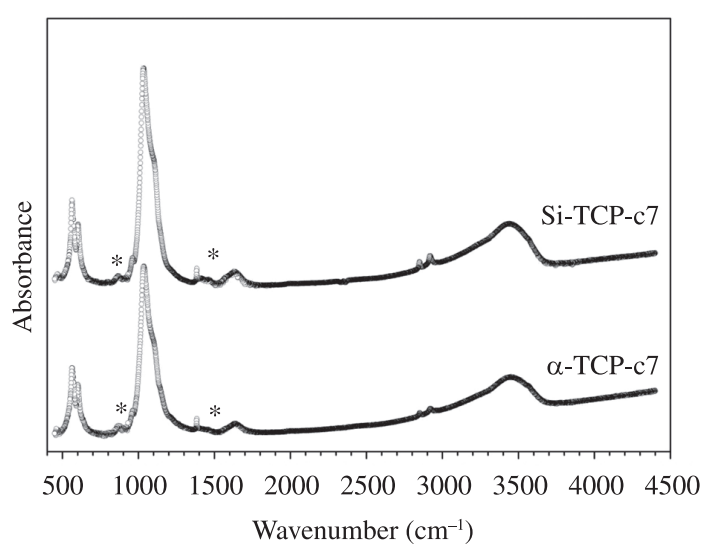

Figure 3. FTIR spectrum of cement samples after 7 days of setting, Si-TCP-c7 and $\alpha$-TCP-c7. “*” represents $\mathrm{CO}_{3}{ }^{2-}$ absorbance bands.

Cements fracture surface after 7 days of immersion can be observed on Figure 5. Silicon doping has resulted on smaller apatite crystals ${ }^{4}$ with morphology much similar to the biological apatite.

\section{Discussion}

The lower content of $\beta$-TCP on Si- $\alpha$-TCP confirms the efficiency of Silicon in stabilizing the $\alpha$-TCP phase by lowering the $\beta \rightarrow \alpha$ phase transformation temperature ${ }^{4,5,22}$ once the powder doped with Silicon resulted on purer $\alpha$-TCP (4 wt. (\%) of $\beta$-TCP) at a lower sintering temperature 
$\left(1250{ }^{\circ} \mathrm{C}\right)$. Based on results reported on the literature ${ }^{22-24}$ depending on the Magnesium content in the precursors employed the temperature at which pure $\alpha$-TCP can be synthesized could be raised up to $1500{ }^{\circ} \mathrm{C}$, however, if the material is sintered at the right temperature and for enough time to guarantee the total $\beta \rightarrow \alpha$ conversion it is possible to obtain pure $\alpha$-TCP no matter how high is the $\mathrm{Mg}$ contamination. Then, if the powders synthesized on this

Table 5. FTIR absorption bands of $\mathrm{CDHA}^{20}$.

\begin{tabular}{cc}
\hline Absorption & wavenumber $\left[\mathbf{c m}^{-1}\right]$ \\
\hline $\mathrm{OH}$ extention & 3572 \\
$v_{3}\left(\mathrm{HPO}_{4}\right)$ & 1133 \\
$\delta \mathrm{OH}$ deformation & 1210 \\
& 1087 \\
$v_{3}\left(\mathrm{PO}_{4}\right)$ & 1072 \\
& 1046 \\
$v_{1}\left(\mathrm{PO}_{4}\right)$ & 1032 \\
$v_{5}\left(\mathrm{HPO}_{4}\right)$ & 962 \\
$\mathrm{OH}_{\text {oscilation }}$ & 870 \\
$v_{4}\left(\mathrm{PO}_{4}\right)$ & 630 \\
\hline
\end{tabular}

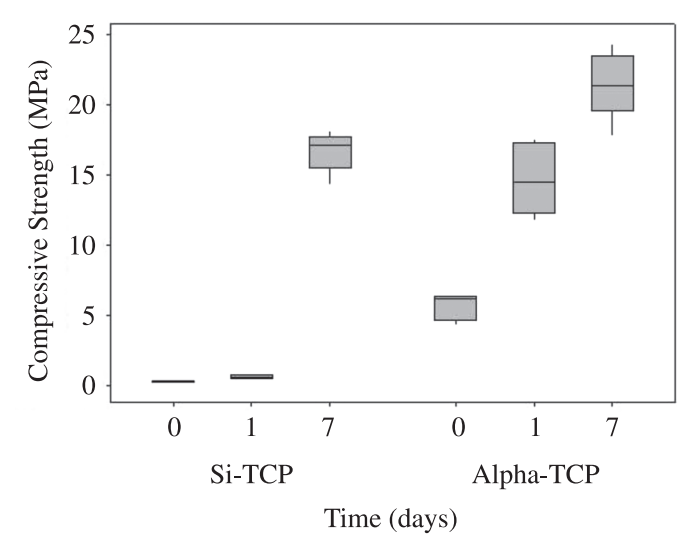

Figure 4. Compressive strength evolution with time. Legend: $0=$ Si-TCP-c0 or $\alpha$-TCP-c0; $1=$ Si-TCP-c1 or $\alpha$-TCP-c 1 and $7=$ Si-TCP-c7 or $\alpha-$ TCP-c7. At initial times Si-TCP did not have anymechanical resistance while $\alpha-$ TCP achieved a satisfactory value. After 7 days of SBF immersion $\alpha$-TCP reached a higher compressive strength $(\mathrm{p}<0.05)$.

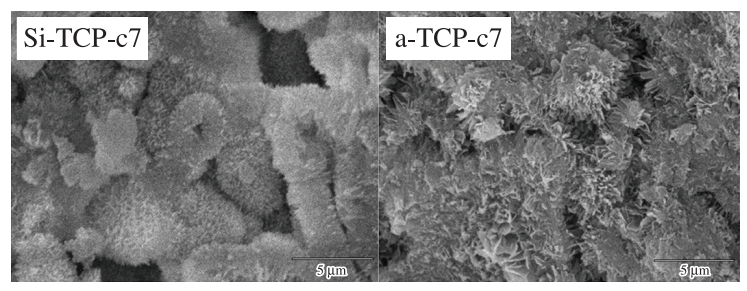

Figure 5. SEM micrographs of cements fracture surface, Si-TCP-c7 and $\alpha$-TCP-c7, after 168 hours of setting. Apatite crystals are smaller for Si-TCP-c7 than for $\alpha$-TCP-c7. work were sintered for longer times it would be expected a reduction on $\beta$-TCP content. Samples purity were also confirmed after $\mathrm{Ca} / \mathrm{P}$ and $\mathrm{Ca} / \mathrm{P}+\mathrm{Si}$ ratios determination since their values are very close to the theoretical ones of TCP ( $\alpha$ and $\beta$ phases) compounds, 1.50 .

During cement preparation, it was determined larger values of setting time. In a first moment, this fact can be explained by the high liquid-to-powder ratio employed $0.60 \mathrm{~mL} . \mathrm{g}^{-1}$ against $0.32-0.34 \mathrm{~mL} . \mathrm{g}^{-1}$ normally used for conventional $\alpha$-TCP cement $^{8,20,21,25}$; however, this huge amount of liquid was necessary to guarantee the cement moldability. Moreover, the addition of citric acid to cement's liquid phases has also contributed to the high setting times since this compound increases the TCP particles' wettability and cement paste fluidity caused by a deflocculation on the TCP powder which also leads to a lower rate of setting reaction ${ }^{26}$. It is important to emphasize that without citric acid addition the liquid-to-powder ratio needed was higher than $1.0 \mathrm{~mL} . \mathrm{g}^{-1}$.

Furthermore, by comparing XRD patterns of Figure 1 it is possible to infer that Silicon induces a reduction on the rate of setting reaction. In the first 24 hours, as it was expected, $\alpha$-TCP $(\alpha$-TCP-c0) started to solubilize together with CDHA precipitation. Surprisingly, for Si-TCP the setting reaction seems not to occur on the first 48 hours ( $\mathrm{Si}-\mathrm{TCP}-\mathrm{c} 0$ and Si-TCP-c1) since only $\alpha$-TCP diffraction lines are observed on the XRD patterns. Finally, after 168 hours, for $\alpha$-TCP cement the TCP $\rightarrow$ CDHA conversion has finished while Si-TCP cement still have some TCP without reacting.

The difference on TCP reactivity is responsible for the lower compressive strength achieved by Si-TCP cement, as displayed on the boxplot chart of Figure 4. At initial times samples "Si-TCP-c0" and "Si-TCP-c1" did not present any mechanical resistance while sample " $\alpha$-TCP-c0" reached $5.6 \pm 0.9 \mathrm{MPa}$. As TCP $\rightarrow$ CDHA conversion evolves samples' compressive strength enhances reaching after 168 hours $21.5 \pm 2.4$ and $14.8 \pm 2.6 \mathrm{MPa}$ for $\alpha$-TCP-c7 and Si-TCP-c7, respectively.

Nevertheless, it is important to observe that even though the mechanical resistance for Si-TCP cement after 168 hour is lower than for $\alpha$-TCP cement, this material had not reached the $100 \%$ TCP $\rightarrow$ CDHA conversion, thus, it is expected that its maximum mechanical resistance became higher after all Si-TCP is converted into CDHA.

\section{Conclusions}

Si- $\alpha$-TCP was synthesized by a simple solid state reaction in which it was employed "Mg-free" reagents leading to lower sintering temperatures for both Si doped and non-doped $\alpha$-TCP. Moreover, calcium phosphate cements obtained employing these TCP powders achieved satisfactory properties; however, Silicon has induced a decrease on the setting reaction velocity.

\section{Acknowledgements}

The authors would like to thank State of São Paulo Foundation (FAPESP) for the financial support. 


\section{References}

1. Döeblin N, Luginbühl R and Bohner M. Synthetic Calcium Phosphate Ceramics for Treatment of Bone Fractures. Mineralogy. 2010; 64:723-729.

2. Dorozhkin SV. Bioceramics of Calcium Orthophosphates. Biomaterials. 2010; 31:1465-1485. PMid:19969343. http:// dx.doi.org/10.1016/j.biomaterials.2009.11.050

3. Ginebra MP, Espanol M, Montufar EB, Perez RA and Mestres G. New processing approaches in calcium phosphate cements and their applications in regenerative medicine. Acta Biomaterialia. 2010; 6:2863-2873. PMid:20123046. http:// dx.doi.org/10.1016/j.actbio.2010.01.036

4. Pietak AM, Reid JW, Stott MJ and Sayer M. Silicon substituition in the calcium phosphate bioceramics. Biomaterials. 2007; 28:4023-4032. PMid:17544500. http:// dx.doi.org/10.1016/j.biomaterials.2007.05.003

5. Reid JW, Tuck L, Sayer M, Fargo K and Hendry JA. Shynthesis and Characterization of Single-Phase Silicon-Substituted $\alpha$-Tricalcium Phosphate. Biomaterials. 2006; 27:2916-2925. PMid:16448694. http://dx.doi.org/10.1016/j. biomaterials.2006.01.007

6. Carlise E. Si: a possible factor in bone calcification. Science. 1970; 167.

7. Carlisle EM. A Silicon Requirement for Normal Skull Formation in Chicks. Journal of Nutrition. 1980; 110.

8. Camiré CL, Saint-Jean SJ, Mochales C, Nevsten P, Wang JS, Lidgren L et al. Material characterization and in vivo behavior of silicon substituted $\alpha$-tricalcium phosphate cement. Journal of Biomedical Materials Research Part B: Applied Biomaterials. 2006; 76B:424-431. PMid:16184531. http:// dx.doi.org/10.1002/jbm.b.30385

9. Arcos D, Sánchez-Salcedo S, Izquierdo-Barba I, Ruiz L, González-Calbet J and Vallet-Regí M. Crystallochemistry, textural properties, and in vitro biocompatibility of different silicon-doped calcium phosphates. Journal of Biomedical Materials Research Part A. 2006; 78A:762-771. PMid:16739108. http://dx.doi.org/10.1002/jbm.a.30790

10. Carrodeguas RG, De Aza AH, Jimenez J, De Aza PN, López-Bravo A and De Aza S. Preparation and in vitro characterization of wollastonite doped tricalcium phosphate bioceramics. Key Engineering Materials. 2008; 361-363:237240. http://dx.doi.org/10.4028/www.scientific.net/KEM.361363.237

11. Wei $X$ and Akinc M. Resorption Rate Tunable Bioceramic: Si\&Zn-Modified Tricacium Phosphate. Ceramic Engineering and Science Proceedings. 2008; 26:129-136. http://dx.doi. org/10.1002/9780470291269.ch16

12. Bohner M. Silicon-substituted calcium phosphates - a critical view. Biomaterials. 2009; 30:6403-6406. PMid:19695699. http://dx.doi.org/10.1016/j.biomaterials.2009.08.007

13. Carrodeguas RG and De Aza S. $\alpha$-Tricalcium phosphate: Synthesis, properties and biomedical applications. Acta Biomaterialia. 2011; 7:3536-3546. PMid:21712105. http:// dx.doi.org/10.1016/j.actbio.2011.06.019
14. Mestres G, Le Van C and Ginebra MP. Silicon-stabilized $\alpha$-tricalcium phosphate and its use in a calcium phosphate cement: Characterization and cell response. Acta Biomaterialia. 2011. http://dx.doi.org/10.1016/j. actbio.2011.11.021 PMid:22154863.

15. Reid JW, Pietak A, Sayer M, Dunfield D and Smith TJN. Phase formation and evolution in the silicon substituted tricalcium phosphate/apatite system. Biomaterials. 2005; 26:2887-2897. PMid:15603784. http://dx.doi.org/10.1016/j. biomaterials.2004.09.005

16. Motisuke M, Carrodeguas RG and Zavaglia CAC. Mg-free precursors for the synthesis of pure phase Si-doped $\alpha-\mathrm{Ca}_{3}\left(\mathrm{PO}_{4}\right)_{2}$. Key Engineering Materials. 2008; 361-363:199-202. http:// dx.doi.org/10.4028/www.scientific.net/KEM.361-363.199

17. Camiré CL, Saint-Jean SJ, McCarthy I, Mochales-Palau C, Lidgren L, Planell JA et al. Production methodology and reactivity of silica substituted $\alpha$ phase tricalcium phosphate. In: Proceedings of the 7th WBC; 2004; Sydney; 2004. p. 17-21.

18. Cullity BD. Elements of X-Ray Diffraction. Indiana: Addion-Wesley Publishing Company Inc.; 1956.

19. American Society for Testing and Materials-ASTM. C266-04: Standard Test Method for Time of Setting of Hydraulic-Cement Paste by Gillmore Needles.

20. Ginebra MP, Fernandez E, De Maeyer EAP, Verbeeck RMH, Boltong MG, Ginebra J et al. Setting Reaction and Hardening of an Apatitic Calcium Phosphate Cement. Journal of Disability Research. 1997; 76: 905-912.

21. Dos Santos LA, Carrodeguas RG, Rogero SO, Higa OZ, Boschi AO and Arruda ACF. Alpha-tricalcium phosphate cement: in vitro cytotoxicity. Biomaterials. 2002; 23:2035-2042. http:// dx.doi.org/10.1016/S0142-9612(01)00333-7

22. Motisuke M, Carrodeguas RG and Zavaglia CAC. Si-Tricalcium phosphate cement: preparation, characterization and bioactivity in SBF. Materials Research. 2011; 14:493-498. http://dx.doi. org/10.1590/S1516-14392011005000065

23. Langstaff S, Sayer M, Smith TJM and Pugh SM. Resorbable bioceramics based on stabilized calcium phosphates. Part I: rational design, sample preparation and material characterization. Biomaterials. 1999; 20:135-150. http://dx.doi. org/10.1016/S0142-9612(99)00086-1

24. Carrodeguas RG, DeAzaAH, Turrillas X, PenaP andDeAza S. New approach to the $\beta \rightarrow \alpha$ polymorphic transformation in magnesiumsubstituted tricalcium phosphates and its pratical implications. Journal of the American Ceramic Society. 2008; 91:1281-1286. http://dx.doi.org/10.1111/j.1551-2916.2008.02294.x

25. Ginebra MP, Fernandez E, Driessens FCM, Boltong MG, Muntasell J, Font $\mathbf{J}$ et al. The effects of temperature on the behavior of an apatitic calcium phosphate cement. Journal of Materials Science: Materials in Medicine. 1995; 6:857-860. http://dx.doi.org/10.1007/BF00134332

26. Sarda S, Fernández E, Nilsson M, Balcells M and Planell JA. Kinetic study of citric acid influence on calcium phosphate bone cement as water-reducing agent. Journal of Biomedical Materials Research. 2002, 61. 